\title{
Embodied ancestors: Religious objects, moral actions and well-being in the Cameroon Western Grassfields
}

\begin{tabular}{|c|c|}
\hline \multicolumn{2}{|c|}{$\begin{array}{l}\text { Authors: } \\
\text { Mathias F. Alubafi'i, } \\
\text { Chammah J. Kaunda }\end{array}$} \\
\hline \multicolumn{2}{|c|}{$\begin{array}{l}\text { Affiliations: } \\
{ }^{1} \text { Human and Social } \\
\text { Development of Human } \\
\text { Sciences Research Council, } \\
\text { Pretoria, South Africa }\end{array}$} \\
\hline \multicolumn{2}{|c|}{$\begin{array}{l}{ }^{2} \text { Department of Sociology } \\
\text { and Anthropology, University } \\
\text { of Limpopo, Polokwane, } \\
\text { South Africa }\end{array}$} \\
\hline \multicolumn{2}{|c|}{$\begin{array}{l}{ }^{3} \text { Global Institute of Theology, } \\
\text { The College of Theology/ } \\
\text { United Graduate School of } \\
\text { Theology, Yonsei University, } \\
\text { Seoul, Korean Republic }\end{array}$} \\
\hline \multicolumn{2}{|c|}{$\begin{array}{l}\text { Corresponding author: } \\
\text { Chammah Kaunda, } \\
\text { pastorchammah@gmail.com }\end{array}$} \\
\hline \multicolumn{2}{|c|}{$\begin{array}{l}\text { Received: } 02 \text { July } 2018 \\
\text { Accepted: } 15 \text { Jan. } 2019 \\
\text { Published: } 10 \text { July } 2019\end{array}$} \\
\hline \multicolumn{2}{|c|}{$\begin{array}{l}\text { How to cite this article: } \\
\text { Alubafi, M.F. \& Kaunda, C.J., } \\
\text { 2019, 'Embodied ancestors: } \\
\text { Religious objects, moral } \\
\text { actions and well-being in } \\
\text { the Cameroon Western } \\
\text { Grassfields', HTS Teologiese } \\
\text { Studies/Theological Studies } \\
\text { 75(1), a5174. https://doi.org/ } \\
\text { 10.4102/hts.v75i1.5174 }\end{array}$} \\
\hline \multicolumn{2}{|c|}{$\begin{array}{l}\text { Copyright: } \\
\text { (c) 2019. The Authors. } \\
\text { Licensee: AOSIS. This } \\
\text { is licensed under the } \\
\text { Creative Commons } \\
\text { Attribution License. }\end{array}$} \\
\hline \multicolumn{2}{|l|}{ Read online: } \\
\hline 回它回 & $\begin{array}{l}\text { Scan this QR } \\
\text { code with your } \\
\text { smart phone or } \\
\text { mobile device } \\
\text { to read online. }\end{array}$ \\
\hline
\end{tabular}

\section{Authors:}

\section{Affiliations:} Sciences Research Counci,

Pretoria, South Africa of Limpopo, Polokwane,

${ }^{3}$ Global Institute of Theology, The College of Theology/ United Graduate School of Theology, Yonsei University,

Corresponding author: Chammah Kaunda,

Dates: Accepted: 15 Jan. 2019

How to cite this article: Alubafi, M.F. \& Kaunda, C.J., 2019, 'Embodied ancestors: gious objects, moral the Cameroon Western Grassfields', HTS Teologiese Studies/Theological Studies 75(1), a5174. https://doi.org/

Copyright: Licensee: AOSIS. This work is licensed under the Creative Commons Attribution License. mobile device to read online.

\begin{abstract}
In African spirituality, ancestor engagement with the community is always mediated through material objects. This article argues that materiality gives meaning and validity to the ancestral system. Ancestral objects are an embodiment of the ancestors or ancestral meaning-making, which links the visible community to the world of the spirits. However, ancestral objects also draw meaning and validation from those who inherit them, such as kings or titleholders who together with them connect the community to the spiritual source of well-being and vice versa. The article argues that such interplay is based on the material, religious and ritual conception of ancestral objects with their inheritors and the well-being of the community they represent. However, most studies on African religious art objects have focussed essentially on the symbolism behind ancestral objects and their motifs rather than on the interplay between ancestral objects and meaning-making in relation to community's well-being. This article sets out to examine this relation and other performative aspects associated with ancestral objects in the Cameroon Grassfields. It argues that Grassfields religious traditions are materially oriented in the way they shape human meaning-making and interpretation of reality, and represent ancestors as manifested reality and living-dead agents who are part of collective communal action.
\end{abstract}

Keywords: Embodiment; Religion; Objects; Western Grassfields; Ancestors; Meaning-making.

\section{Introduction}

The role of ancestors in the lives of their living relatives has been the basis of numerous scholarly studies on African spirituality and culture (Jindra 2005; Koloss 2000; Kopytoff 1997; Mbiti 1969; Nürnberger 2007; Setiloane 1976). In his seminal work on 'Ancestors as Elders in Africa', Kopytoff (1997:412) argues that African spirituality is experienced through a continuous relationship between the living-alive relatives and their ancestors who 'are vested with mystical powers and authority'. The ancestral traditions are internalised and processed as part of daily interactions with the world. Most Africans are aware that their ancestors 'retain a functional role in the life of their living kinsmen; indeed, African kin groups are often described as communities of both the living and the dead' (Kopytoff 1997:412). Kopytoff's observation echoes what most Cameroon Western Grassfields scholars have written and elaborated on this concept (Fardon 1990; Geary 1981; Jindra 1997, 2005). In the Western Grassfields, spirituality is an encounter of the living-alive with the living-dead (ancestors) often through material objects. The ancestors in the traditional religious practices of the Western Grassfields are believed to continue interacting and to engage in the affairs of the community of the living-alive. Materiality is conceived as the locus for continuously experiencing the ancestors' presence and objects as their actual embodiment within the community of life.

The living dead are venerated by family members through materialising their spirits into specific objects, which function as media of encounters with the living-dead (Nürnberger 2007). These objects are indispensable to the survival, prosperity and well-being of the community. Failure to propitiate the death is believed to result in various forms of misfortunes, and this can sometimes retard the future prosperity and well-being of the community. Ancestral propitiation is done through the media of objects, most of which have been handed down from generation to generation (Arnoldi, Hardin \& Geary 1996; Brain \& Pollock 1971; Fubah 2016; Gebauer 1979; Kaunda 2018). These ancestral objects are perceived as spaces of intersection between materiality and spirituality - as embodiment of the spirits of ancestors. They allow ancestors to continue playing a critical role in the world of the living-alive relatives (Brain \& Pollock 1971; Fubah 2016; Gebauer 1979). 
For the ancestral objects to promote well-being among the community in the Western Grassfields they have to be activated, which can only be done by legitimate living relatives or representatives of the ancestors (in this case the successor). Without activation by a legitimate person(s), they remain as mere objects. For instance, the drinking horn and the traditional stool in the Western Grassfields are an embodiment of the royal ancestors, but they are believed to be activated only when a legitimate king or titleholder drinks from the horn or sits on the stool. It is at this stage that the traditional stool and the legitimate king are unionised (king-stool relation) as material embodiment, expressions and representation of the presence of the ancestors, among their relatives.

Such associations are based on the material, religious and ritual conception of the traditional stool, and kingship relations are believed to have significant implications for the well-being of the community they represent (Arnoldi et al. 1996; Crossland 2014; Fubah 2016; Kaunda 2015). This shows that meaning and religious imaginations are socially and contextually derived and situated and function to represent the community's moral vision of a life-giving society. The material objects embody not only the spirits of the ancestors but also fundamentally the historical moral foundation upon which the community was originally established.

However, most studies on African religious objects have focussed essentially on the symbolism behind ancestral objects and their motifs rather than the 'king-stool' or 'titleholder-stool' interplay as material embodiments of the ancestors with implications for community prosperity and well-being (Kaunda 2018). This article sets out to examine the 'king-stool' relation and other performative aspects associated with royal stools and drinking horns in the Cameroon Western Grassfields. It argues that people look for a reality higher than themselves to sanction or validate those moral actions they believe are crucial for the well-being of the whole community. Thus, king-stool relations or king-drinking horn relations are meaningful only to the extent that the community's moral actions are aligned with the values they represent aside from the ancestors themselves.

In other words, sacred instruments are important in as much as they give the community not only a life-giving interpretation of reality but also impetus to adhere to social norms that are foundational to collective well-being.

\section{The Western Grassfields and 'eldership complex'}

The Cameroon Western Grassfields stretches from the expansive rainforests in the South and West of the country to the upper reaches of the Mbam River on the Nigerian border. The Grassfields is the highland, which sits at approximately $1000 \mathrm{~m}-3000 \mathrm{~m}$ above sea level and belongs to the savannah belt which runs from the Atlantic right across the continent to the Indian Ocean. The border between the forest and the
Grassfields does not only mark two geographically and climatically distinct areas but also separates two entirely different cultures. The forests are inhabited mostly by small population groups with small chiefdoms and are counted among the egalitarian and acephalous societies in academic literature (Koloss \& Homberger 2008). The Grassfields, on the contrary, are a land of monarchic systems. The various kingdoms of the Grassfields resemble each other in key areas - religious ideas, tools, weapons, clothes, houses and settlements - but there are also significant differences (Argenti 1998; Fubah 2017; Geary 1981; Jindra 2005; Koloss \& Homberger 2008). The languages and dialects, for example, do not always allow for unambiguous communication between neighbours, and to this day, Pidgin English, English and French serve as linguae francae (Koloss \& Homberger 2008). ${ }^{1}$ Many of these kingdoms are renowned for their 'masquerades as well as for their elaborate hierarchies headed by kings, who are known throughout the region by the Pidgin term, fon (Argenti 1998:753) or for in Bambui (Fubah 2014) and foyn in Kom (Nkwi 1996).

These hierarchies are generally centralised in the palace in the capital, and are divided into a tripartite system composed of the king; kwifor or a regulatory society of commoners, including servants, advisors and a judiciary body; and the society of royal eligibles (the king's sons and his predecessors' sons) (Argenti 1998).

The regulatory society and the royal eligibles are both divided into ranks according to complex title systems, which confer unequal decision-making powers (cf. Gramci 1971), as well as a sartorial prerogative on the occupants of the royal household (Argenti 1998). Of all the traditional regalia of the traditional elites or royals, the drinking cup and the stool are the most important (Fubah 2014). This is because the king or titleholder sits on the ancestral stool and uses his drinking horn (which is considered a titled cup or an ancestral cup) to pour libation to the ancestor(s). There are two categories of drinking horns, including the buffalo horn drinking cup, which is reserved for members of the royal family, most of whom are titled holders, and the cow horn drinking cup used by all members of the society (Knöpfli 1997). The production of drinking horns is also highly stratified. Essentially, the buffalo horn drinking cup is carved by special artists, whose work is recognised and appreciated by the fon, while the cow horn drinking cup is produced by all artists, regardless of their status. Similarly, the stool of the king or titleholder is carved by special artists whose work is recognised and appreciated by the fon or the titleholder. The drinking horn and the stool are handed down to a chosen successor or fon or titleholder when the sitting person 'goes missing' or dies. In the Western Grassfields and in most African societies, it is believed kings do not die, they only 'go missing' or disappear and will re-appear (Bonu 2012; Fubah 2018; Koloss 1987). It is at this stage that ancestral propitiation

1.It should be noted that French is spoken only in the Grassfields regions that belong to the former East Cameroon, such as the Bamum and Bamileke regions in the to the former East Cameroon, such as the Bamum and Bamileke regions in the
Western Province. In the Grassfields regions that belong to the former West Cameroon, the linguae francae are Pidgin English and English. 
sets in even though the previous person was performing similar duties. The new person continues from where his predecessor ended, but the drinking horn or stool is only meaningful and powerful when put to use by the legitimate person, successor or titleholder. This is discussed further below.

In his famous paper 'Ancestors as Elders in Africa', Kopytoff (1971) rejects the conceptual separation of the world of the living from the world of the dead (see also Kaunda 2013, 2015). He argues that this conception distorts the African model of reality. Kopytoff (1971) stresses the use of indigenous terms when discussing African religious heritage to reflect more closely the African cosmological concepts. His main argument is that there is no major difference between dead ancestors and the living elders in the belief practices of the living. He maintains that many African peoples do not have a classificatory distinction between ancestors and elders and that this represents the lack of a classificatory distinction in the emic model.

He goes on to note that he prefers to replace terms such as 'cult' and 'worship' with a term that he feels more correctly reflects African perceptions, such as 'eldership complex' (Kopytoff 1971). In doing this, Kopytoff (1971) based his claim on the fact that Africans do not make any major distinction between ancestors and elders because differential and respectful behaviour towards both is a reflection of a gerontocratic system where juniors must honour and respect anyone senior to them.

Responding to Kopytoff's arguments, Brain (1976) notes that the use of the term 'worship' is an unfortunate one. In contrast to Kopytoff, however, Brain notes that the retention of the term 'cult' is unjustified. In particular, Brain (1976) accepts the conceptual separation of the world of the ancestors and the world of the living as being an emic one and therefore valuable, and went ahead to uphold that differences exist between living elders and ancestors in terms of respect from social juniors. Still in response to Kopytoff's views about living elders and ancestors, Sangree (1974:70) argues that Kopytoff's thesis does disservice to the ethnography of most African societies. In Sangree's (1974:70) view, distinctions exist between the living elders and the ancestors in indigenous African societies, which reflect and reinforce their respective structurings and resolutions of inter-generation conflict.

Mendonsa (1976:57) argues that when a person dies, his or her 'spirit is incorporated into a collectivity of ancestors, which correspond to a unilineal descent group among the living'. He or she is propitiated at that group's ancestral shrine and is thought to remain interested in the remaining living relatives. However, as many African scholars such as Mbiti (1969) and Setiloane (1976) argue, the privilege of becoming ancestors is reserved for people who lived their lives well on earth, who were morally upright and who upheld the ethics of common good and promoted the well-being of their families and communities. These are the ones who qualify to become custodians of the land that their descendants inhabit. They are the guardians of the community affairs, customs, traditions and ethical norms that promote the common good (Ikenga-Metuh 1987; Mbiti 1969; Setiloane 1976). This means that ancestors do not become what they were not before they died. However, having lived well before death earns the ancestors a mediatorial function, which is divinely entrusted to them as arbitrators between the Supreme Being and the community of their living descendants. This responsibility is higher than the role of living-alive elders in the community (Kaunda 2013). As Mendonsa (1976:57) notes, ancestors are provided with divine power to punish the living members of the descent group. This is a powerful mechanism for social control in the Western Grassfields and, by extension, in most African traditional societies. It is believed that custom and tradition are upheld by the belief in ancestral affliction. Titled individuals and elders are also 'believed to live after death and become ancestors themselves', likewise capable of influencing the destinies of their respective families (Jindra 2005:358). Thus, their power is transferred into a flat stone and a title cup before they are buried when they die.

We will argue in favour of Kopytoff's thesis that the world of living elders and the world of ancestors are two sides of the same coin because the actions of the living elders are directly linked to what they believe as the dictates of their ancestors. Such a link is manifested through the material objects such as stools and drinking horns left behind by the ancestors and are used for their propitiation, especially in the Western Grassfields. To this end, we agree with Kopytoff that the appropriate term for 'worship' and 'cult' in reference to living elders and ancestors is an 'eldership complex' that brings together the ancestors, living elders, material objects and the actions that emerge from these to determine the state of prosperity and well-being of the society.

\section{The ancestral drinking horn and stool in the Western Grassfields: Past and present}

Here, we return to the activation of the drinking horn and the stool mentioned earlier. An explanation of the process of transforming the drinking horn into an ancestral object that is then activated by the legitimate successor, the living fon or titleholder, is necessary here. The drinking horn in Figure 1 is initiated into a title cup when a family head, the fon or a subchief, for example, dies.

One of the major rituals performed when a notable person or titleholder dies in Bambui and the Western Grassfields is to initiate his or her drinking horn before he or she is buried (Fubah 2016). This is done by placing the deceased person's drinking horn and a small stone on his or her forehead to transfer his or her spirit and whatever power he or she possessed to the drinking horn. It is believed that the dead person's spirit and power is added to any other vestiges of 


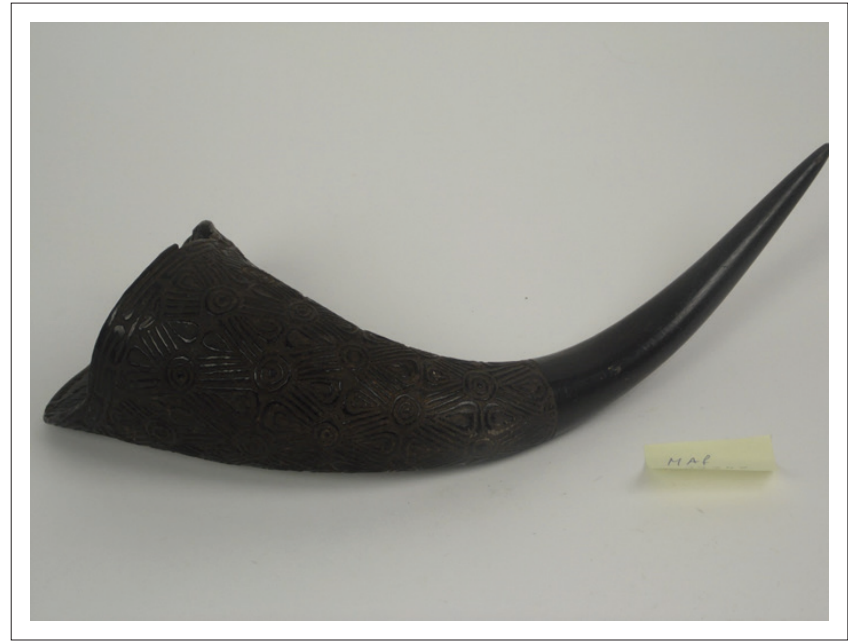

Source: Photo taken by Mathias A. Fubah, Grassi Museum Leipzig, June $2014^{2}$

FIGURE 1: Buffalo horn drinking cup with ornaments.

ancestral power in the horn because most of them have been inherited from previous generations.

In a situation where the deceased person does not own a drinking horn or title cup, one may be purchased and used in this ritual to ensure that he or she leaves behind an ancestral cup that will eventually be handed to his or her successor. ${ }^{3}$ A major problem with the new cup is whether it can be considered powerful or authentic.

To some commentators, the new title cup does not represent or possess the power of all the ancestors of the family because it was never used by the deceased. The implication here is that the drinking horn may not have influence on the community even when used by a legitimate fon or titleholder. To others, a new horn represents the entire family because the deceased whose power has been transferred to the new title cup was the overall representative of the ancestors, his or her family and families under them (Fubah 2016). The argument here is that the power of the title cup cannot obviously solely depend on the wear and tear of the material objects but also includes the position of the deceased as connected to or representative of the ancestors. It can, thus, be negotiated. After all, as argued, 'the authentic is not a fixed property of an object or a situation, but is a negotiated attribute with multiple dimensions whose status is evaluated differently by different assessors' (Xie \& Wall 2003:111). Elders with ranks similar to the deceased perform the initiation rituals. Thus, a member of the traditional elites performs the initiation rites for a title cup belonging to a member of the traditional elites

2.Black colour external surface. The horn is decorated with geometric designs. It was collected by one of the German explorers in the Kingdom of Bamum in the Grassfields in 1907 and was donated to the Grassi Museum in Leipzig by Thorbecke. The horn is currently part of the Cameroon Grassfields collection at the Grass Museum, Leipzig, Germany. Buffalo horns are used exclusively by fons or kings and titleholders in the kingdoms of the Grassfields. The buffalo is considered a roya animal and as a result everything that has to do with the buffalo is reserved for royals and elites. All the photographs in this article were taken by Mathias A. Fubah, Leipzig, June 2014.

3.It is worth noting that the successor can be a man or woman depending on the circumstance. In the case where the deceased is a woman, her successor will be woman and when it is a man, the successor will be a man. However, there are also cases where a female can be a regent successor for a man who does not have a male child until such time that a man is chosen from the family or when one of the man's daughters give birth to a son who can occupy the throne. and a peer among the urban classes does that of a member of the modern urban elite.

Similarly, the cups given to manyis [the mother of twins] are initiated by other manyis, and are signs of a particular status not usually accorded to other women.

The placing of the title cup and the small stone on the deceased's forehead is usually followed by incantations, beseeching the living dead to go with 'dry or empty hands and leave behind fresh hands' to look after his or her family and their descendants. The 'fresh hands' in this context refer to the power transferred from the deceased to the title cup, while 'dry hands' stand for the deceased's continuous role in keeping the 'fresh hands' even fresher.

Put differently, the deceased should never relent in his or her effort in looking after the well-being of the family left behind. Once the ritual of transfer of power is complete, the title cup is put into a special bag and stored in a secret location in the deceased's house until after his or her second funeral celebration. ${ }^{4}$ It is eventually handed over to the rightful successor together with other ancestral objects such as stool, cap, table, dress and related paraphernalia at a traditional religious ceremony known as aso-ohnjiendieu or empowerment of a titleholder, attended mostly by other titleholders. The small stone is placed at a corner of the fon or titleholder's living room where periodic libation is performed using the drinking horn or cup.

The other significant ancestral object for the purpose of this article is the ancestral stool. Figure 2 shows the traditional stool for the fon.

Across the Western Grassfields, sculpted seats or stools are carved and reserved exclusively for the fon or titleholder. The form, size and decoration on each of the seats depend on the status of the owner in the community. Royal seats or stools in the Bambui Kingdom in the Western Grassfields, for example, can be divided into ceremonial thrones (in the form of chairs) with a large back and portable stools, which can be combined with other royal objects (Notue \& Triaca 2005). Each of these categories can include several types which vary in shape and decoration. These thrones and stools are used in various ceremonies; they are some of the most important and impressive symbols of royalty and eldership across Grassfields Kingdoms. Some of them express the sovereignty of the fon, representing the monarch himself to such a degree that honour is rendered to the stools and thrones even when the fon is not seated on them or using them. Unlike the drinking horn that is used for transferring power from the deceased before burial, power is not transferred from the

4.The second funeral is the celebration that follows the first funeral or burial rites by a year or more in the Western Grassfields. In the past, most second funerals were conducted 10 years or more after the burial rites. This was dependent on the means conducted lo years or available to the is funeral celebrations were costly in the past and family members needed enough time to raise money for the event. Nowadays, second funerals are performed in day or two following the burial rites. The reason for this recent development is costcutting. Once the second funeral is celebrated, the deceased who is believed to be wandering after death becomes an ancestor who can now influence the lives of his or her living elders or kinsmen. 


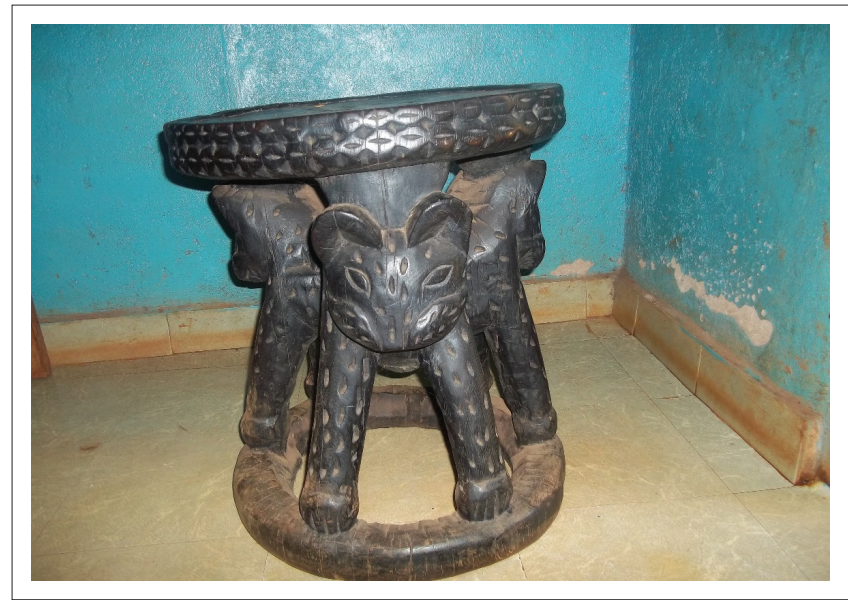

Source: Photo taken by Mathias A. Fubah, Grassi Museum Leipzig, June $2014^{2}$ FIGURE 2: Ancestral stool for the king.

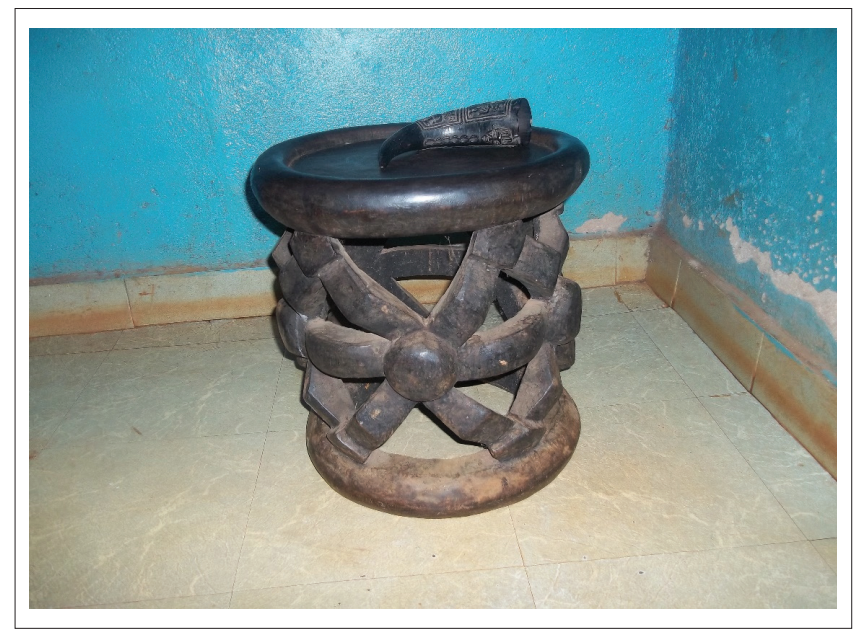

Source: Photo taken by Mathias A. Fubah, Grassi Museum Leipzig, June $2014^{2}$ FIGURE 3: The drinking horn on top of the ancestral stool.

deceased into the stools and thrones. However, it is believed that when the fon or titleholder carries the drinking horn and sits on the stool or throne, it is activated as this is the same stool and throne that was used by the predecessor who is now an ancestor. Figure 3 shows the traditional horn on the ancestral stool.

Hence, the use of the drinking horn in pouring libation while sitting on the ancestral stool or throne is believed to unionise the fon or titleholder and the objects and activate communication with the ancestors, which has a strong bearing on the prosperity and well-being of the living family members. It can be argued that it is not only celebrations and sacrifices or symbols represented on the objects that are crucial for ancestral benevolence or punishment, but also the transfer of the power of the deceased into the title cup and small stone - the legitimacy of the user of the cup while sitting on the ancestral stool. All these aspects are embodied means of communication with the ancestors. This demonstrates that these objects are crucial in representing ancestors as a living, knowable and experiential reality within the material world. In other words, these objects are not merely symbols (Bae
2007), but the very manifestations of the ancestors in the material and rational world.

\section{Manifested religions in the Western Grassfields}

Grassfields people, irrespective of their economic situation, believe consciously or unconsciously that celebrations and sacrifices to the ancestors using objects such as the drinking horn and stools or throne are essential for the survival and well-being of the family and society. The question is, how does the ancestral spiritual system function? Is there some form of magic that initiates the process of well-being or is it just people's own realignment of social actions? What role do the ancestral objects play in promoting and strengthening social values as well as shaping moral actions for the common good? To begin with, it is important to stress that to the extent that Grassfields religious meaning-making takes a similar approach to non-religious meaning-making or ways of knowing, embodiment and materiality play a crucial role in the process. The ancestral drinking horn and stool make sense as embodiment of ancestors within the community in which these beliefs and practices are socially constructed and accepted. As already argued, the moral character of the fon or titleholder is inseparable from the manifested reality of the ancestors within the objects. In essence, the moral character of the fon or titleholder is only legitimate to the extent that it manifests the moral traditions of ancestors (Geary 1986; Jindra 1997, 2005; Kaunda 2018; Koloss 1987; Magesa 1997; Ndambi 1993; Ofon 1992). According to Magesa (1997:35), for the fon to remain legitimate, he or she has to continue legitimating themselves before the ancestors through acts of justice, peace, love, good governance and hospitality to the ancestors' people. The Grassfields religious system of thought is grounded in ancestral morality which is believed to have originated and flows from the Supreme Being through the ancestral objects including the legitimate successor into the community and ecological order (Bonu 2012). In the Grassfields' system of thought, 'God is the initiator of the people's way of life, its tradition' (Magesa 1997:35). The ancestors are custodians of such morality, the reason for its establishment and its ultimate purpose (Bonu 2012; Fubah 2018).

Fortes and Evans-Pritchard (1940:19) argue that the ritual functions of the fons or titleholders are not simply meant to sanction political authority or serve as symbolic enactments of the ancestors. Rather, they (Evans-Pritchard 1940):

[S]erve, also, as a sanction against the abuse of political power and as a means of constraining political functionaries to perform their administrative obligations as well as their religious duties, lest the common good suffer injury. (p. 19)

As Geary (1986) and Koloss (1987) argue, the fons and ancestral objects are not just political instruments but are the divine embodiment of their people's prosperity, health and welfare. Mbiti stresses that such ancestral objects may be meaningless, the legitimate successor may not even have 
outstanding skills and abilities needed for kingship, but in the eyes of the community, he or she is the embodiment of ancestors and social norms. Fortes and Evans-Pritchard (1940) note that the fon:

is not to his people merely a person who can enforce his will on them. He is the axis of their political relations, the symbol of their unity and exclusiveness, and embodiment of their essential values. (p.16)

Hence, the fon is addressed as mbeih to symbolise the central role he plays in the society - subjects clap their hands when greeting him, subjects do not shake hands with him, subjects must bow when greeting or delivering a message to the fon and the fon only drinks from a special cup - the buffalo horn (Fubah 2018). Anything short of the aforementioned makes the fon to be seen as a mere person.

The forgoing discussion is essential as the ancestral objects that are ritualistically passed on to the fons or titleholders represent manifested religious knowledge and ontological morality which is socially constructed and the whole community committed and obligated itself to realise and actualise for the sake of their wholeness. However, actualising an ideal society is always a process in which actualisation is inseparable from that which is still possible. In other words, the ancestral system helps the community to continue thriving to realise the whole, which is always ahead as a quested moral vision.

Magesa (1997) describes this moral vision as grounded in the quest for maintaining balance of relational and social rhythm of life among forces of ecology, humanity and the spirits including the Supreme Being and ancestors. Any disturbance to the rhythm of life brings misfortunes, which are too often attributed to ancestors as punishment. Clearly, the ancestors do not bring afflictions or misfortunes on their community but the community's own wrong actions. For example, ancestral system is important for the well-being of both the people and the environment. The failure to follow the rules that prohibit (taboo) hunting in particular seasons, such as during mating periods, is regarded as a breach in the rhythm of life. Such a breach can result in disturbing the animals during a period of creating offspring to replenish the population. The depletion of the population of animals could result in the loss of a constant source of protein and other nutrients for the community.

Therefore, ancestral morality is significant 'in enabling people to realise that they could not expect more from the environment than they could from the investment of love, nurturing and protection' (Kaunda 2016:189).

Such breaches in the relational wholeness do not merely disappear but require 'restoration of wholeness and balance in life' (Magesa 1997:195). This may mean that the community goes without hunting for the whole year to allow animals to repopulate.

Thus, the institution of fon-ship and titleholders together with the ancestral objects that define and orient the moral imaginations of the whole community are crucial in helping the community to constantly reflect and re-evaluate their relations with various relational forces within the rhythm of life. They function as mirrors through which every member of the community gazes at and search for life according to the ethos, values and beliefs of the community that aim at promoting solidarity and well-being (Magesa 1997:31). As Bujo (2003:44) puts it, the kingship as locus for moral imagination of the community plays an active role in shaping a meaningful and moral action for all. Every member of the community reflects, evaluates and participates in shaping and living out this moral action. In other words, it is on the king-stool system that every action by members of the community is weighed and found wanting. The underlying assumption is based on the conviction that well-being is the result of right and just actions by every member of the community as set by ancestral moral rhythm reflected in the life and governance of the fon. The lack of social wholeness and prosperity is too often ascribed to the moral failure of the fon (Bonu 2012; Fubah 2018; Koloss 1987; Ndambi 1993). This means that the ancestor system is significant in as much as it functions as the epicentre for moral socialisation of the community for the common good.

However, the ancestral system has no value and meaning without material objects, which function as their embodiment, and further, the material objects themselves have no value without right and just actions by the community members themselves (Fubah 2014, Alubafi \& Ramphalile 2017). It follows, therefore, that the ancestral objects together with the belongings of fons and titleholders are only of significance as manifestations and mediations of social-historical meaning and moral vision of a just and equitable society. However, as already highlighted concerning the use of new cups rather than traditional horns, socialhistorical meaning and their moral visions are increasingly being contested in many contemporary African societies. Much of the historical depth and authority that ancestral objects and fons or titleholders had in traditional systems received little or no respect from modern elites who have acquired such titles through education and material wealth (Fubah 2017, 2018). As already demonstrated, the modern elites have contextualised and given new meanings to ancestral objects in varying modern categories, such as materialistic and neo-capitalistic, or discarded them altogether as it is in an African Pentecostal religious context. African Pentecostalism perceives ancestral objects as an embodiment of demonic forces from which those who are born again must seek liberation to experience prosperity and well-being (De Bruijn, Van Dijk \& Foeken 2001; Kaunda 2017, 2018; Maxwell 2006). Indeed, ancestral objects in contemporary African society and cultural orientation are being adapted and appropriated into new idiomatic meanings, which dialectically differ from those of traditional past. However, whatever the innovation in which ancestral spirituality is interpreted, they remain manifested in religious thought which materialised within daily experiences and reflects the beliefs of most Africans and even those who have 
converted to new religious systems continue to interact with them in various ways, however negative that might be. They remain an embodiment of unwritten moral systems, which have found new meaning within the changed African religious, social, relational and moral landscape.

\section{Conclusion}

The article argues that ancestral objects are perceived as an embodiment of ancestors or ancestral meaning by which the moral existence of the community is framed. It argues that people look for something other than themselves to sanction or validate social actions, which have implications for the well-being of the whole community. Thus, king-stool relations are meaningful only to the extent that the community's actions are aligned with the values that promote well-being. In other words, sacred instruments are important in as much as they give the community not only a life-giving interpretation of reality and meaning to their collective social-relational existence but also function as impetus to adhere to social norms that are foundational to the community well-being.

\section{Acknowledgements}

\section{Competing interests}

The authors declare that they have no financial or personal relationships that may have inappropriately influenced them in writing this article.

\section{Authors' contributions}

M.F.A. was the project leader and was responsible for methodology; formal analysis; fieldwork; and writing, reviewing and editing of the original draft. C.J.K. did most of the conceptualisation; methodological development; theorising; formal analysis; and writing, reviewing and editing of the original draft.

\section{Ethical consideration}

This article followed all ethical standards for a research without direct contact with human or animal subjects.

\section{Funding}

This research received no specific grant from any funding agency in the public, commercial, or not-for-profit sectors.

\section{Data availability statement}

Data sharing is not applicable to this article as no new data were created or analysed in this study.

\section{Disclaimer}

The views and opinions expressed in this article are those of the author and do not necessarily reflect the official policy or position of any affiliated agency of the author.

\section{References}

Argenti, N., 1998, 'Air youth: Performance, violence and the state in Cameroon', Roya Anthropological Institute of Great Britain and Ireland Journal 4, 753-782. https:// doi.org/10.2307/3034831

Arnoldi, M., Hardin, K. \& Geary, C., 1996, African material culture, Indiana University Press, Bloomington, IN.

Bae, C.S., 2007, 'Ancestor worship and the challenges it poses to the Christian mission and ministry', PhD thesis, University of Pretoria, South Africa.

Bonu, C., 2012, A short history and traditions of Bambui: 1700-2012, Reignite Action for Development, London.

Brain, R. \& Pollock, A., 1971, Bangwa funerary sculpture, Gerald Duckworth \& Co., London.

Brain, J.L., 1973, 'Ancestors as elders in Africa-further thoughts', Africa, 43(2), $122-133$.

Bujo, B., 2003, Foundations of an African ethic: Beyond the universal claims of western morality, Paulines, Nairobi.

Crossland, Z., 2014, Ancestral encounters in highland Madagascar: Material signs and traces of the dead, Cambridge University Press, New York.

De Bruijn, M., Van Dijk, R. \& Foeken, D., 2001, Mobile Africa: Changing patterns of movement in Africa and beyond, Brill, Leiden.

Fardon, R., 1990, Localizing strategies regional traditions of ethnographic writing, Scottish Academic Press, Edinburgh; Smithsonian Institution Press, Washington.

Fortes, M. \& Evans-Pritchard, EE, (eds.) 1940, 'African Political Systems', Oxford University Press, London.

Fubah, M., 2014, 'The changing life of the buffalo and cow horn and new ways of adaptation by carvers and patrons in the Grassfields, Cameroon', African Studies, 73, 41-57.

Fubah, M., 2016, 'Museums in the palaces of the Western Grassfields: Concerns about accessibility and sustainability', HSRC Policy Brief, viewed n.d., from http://www. hsrc.ac.za/en/research-outputs/view/7978.

Fubah, M., 2017, 'The shifting iconography of the drinking horn in the Western Grassfields, Cameroon', Cogent Social Sciences 3(1), 1-19.

Fubah, M., 2018, Bambui arts and culture, Cambridge Scholars Publishers, Newcastle.

Geary, C., 1981, 'Bamum thrones and stools', African Arts 14, 32-88. https://doi. org/10.2307/3335758

Geary, C., 1986, 'Burying mothers of crops: Funerals of prominent women in Weh, Western Grassfields, Cameroon', paper presented at African Studies Association Meeting, 1986.

Gebauer, P., 1979, Art of Cameroon, Portland Art Museum and Metropolitan Museum of Art, New York.

Gramci, A., 1971, 'Selections from the prison notebooks', trans., in G. Nowell Smith \& Q. Hoare (eds.), International Publishers Co, New York, NY.

Ikenga-Metuh, E., 1987, Comparative studies of African traditional religions, Imico Publishers, Onitsha.

James, B., 1973, 'Ancestors as elders in Africa: Further thoughts', Africa: Journal of the International African Institute 43(2), 123-133.

Jindra, M., 1997, 'The proliferation of ancestors: Death celebration in the Cameroon Grassfields', PhD Dissertation, University of Wisconsin-Madison.

Jindra, M., 2005, 'Christianity and the proliferation of ancestors: Changes in hierarchy and mortuary ritual in the Cameroon Grassfields', Africa: Journal of the International African Institute 75, 356-377. https://doi.org/10.3366/afr.2005. 75.3.356

Kaunda, C.J., 2013, 'Imagining a just and equitable African Christian Community' A critical analysis of the contribution of theological education fund/ecumenical theological education (1910-2012)', PhD dissertation, University of KwaZuluNatal.

Kaunda, C.J., 2015, 'Denial of African agency: A Decolonial theological turn', Black Theology: An International Journal 13, 1-23. https://doi.org/10.1179/147699481 $5 Z .00000000048$

Kaunda, C.J., 2016, 'Towards an African ecogender theology: A decolonial theological perspective', Stellenbosch Theological Journal 2, 177-202. https://doi.org/ 10.17570/stj.2016.v2n1.a09

Kaunda, C.J., 2017, 'A Nation "sold to the enemy": Zambian Pentecostalism and Kaunda' humanism', Theologia Viatorum 41, 49-80.

Kaunda, C.J., 2018, “The Altars are holding the nation in captivity': Zambian Pentecostalism, nationality, and African religio-political heritage', Religions 9, 145. https://doi.org/10.3390/rel9050145

Knöpfli, H., 1997, Crafts and technologies: Some traditional craftsmen of the Grassfields Cameroon, p. 107, Occasional Paper, British Museum, London.

Koloss, H., 1987, 'Feyin und die Lehre vom Keyus', Baesler Archiv, N.F. Band XXXV, 383-453.

Koloss, H., 2000, World-view and society in Oku, Cameroon, Dietrich Reimer, Berlin.

Koloss, H. \& Homberger, L., 2008, 'The Cameroon Grassfields: A history of research', in L. Homberger (ed.), Cameroon: Art and kings, Rietberg Museum, Zurich. pp. 8-21

Kopytoff, I., 1971, 'Ancestors as Elders in Africa', Africa: Journal of the International African Institute 41(2), 129-142. https://doi.org/10.2307/1159423 
Kopytoff, I., 1997, 'Ancestors as elders in Africa', in R.R. Grinker, S.C. Ubkemann \& C.B. Steiner (eds.), Perspectives on Africa: A reader in culture, history and C.B. Steiner (eds.), Perspectives on Africa: A reader
represtion, pp. 412-422, Blackwell Publishers, Oxford.

Magesa, L., 1997, African religion: The moral traditions of abundant life, Orbis, New York.

Maxwell, D., 2006, African Gifts of the Spirit: Pentecostalism and the Rise of a Zimbabwean Transnational Religious Movement, James Currey, Oxford.

Mbiti, J., 1969, African religions and philosophy, Heinemann, London.

Mendonsa, E., 1976, 'Elders, office-holders and ancestors among the Sisala of northern Ghana', Africa 46(1), 57-65. https://doi.org/10.2307/1159093

Ndambi, I., 1993, 'The case of the Oshie Clan in Momo division', in S. Mbunwe, P. Mzeka, M. Niba \& C. Wirmum (eds.), Rites of passage and incorporation in the Western Grassfields, Cameroon, Kaberry Research Centre, Bamenda. pp. 124-150

Nkwi, P., 1996, 'A conservation dilemma over African royal art in Cameroon', in P. Schmidt \& R. McIntosh (eds.), Plundering Africa's past, pp. 99-109, Indiana University Press, Bloomington, IN.
Notue, J. \& Triaca, B., 2005, Mankon: Arts, heritage and culture from the Mankon Kingdom. Catalogue of the Mankon Museum, 5 Continents, Milan.

Nürnberger, K., 2007, The living dead and the living God, Cluster Publications, Pietermaritzburg.

Ofon, L., 1992, 'Akhu traditional belief life after death', Thesis, St Thomas Aquinas Major Seminary, Bambui.

Sangree, W., 1974, 'Youths as elder and infants as ancestors: The Complementarity of alternative generations, both living and dead, in Tiriki, Kenya, and Irigwe', Africa. Xliv. I, 65-70. https://doi.org/10.2307/1158567

Setiloane, G.M., 1976, The image of God among the Sotho-Tswana, Balkema, Rotterdam.

Xie, P. \& Wall, G., 2003, 'Authenticating Visitor Attractions Based Upon Ethnicity', in A. Fyall, B. Garrod, A. leask, (eds.), Managing Visitor Attractions: New Directions, pp. 107-123. Elsevier Butterworth Heinmann, London. 